\title{
Using Competence Modeling to create Knowledge Engineering Team
}

\author{
Aline T. Nicolini ${ }^{1}$, Cristina S. Santos ${ }^{2}$, Hugo Cesar Hoeschl, Dr. ${ }^{3}$, Irineu \\ Theiss, M.Sc. ${ }^{4}$, Tânia C. D. Bueno, Dr. ${ }^{5}$ \\ 'Master Program in Engineering and Knowledge Management of the \\ Federal University of Santa Catarina - alinen@jijuris.org \\ ${ }^{2}$ Master Program in Engineering and Knowledge Management of the \\ Federal University of Santa Catarina - cristina@ijuris.org \\ ${ }^{3}$ Institute of Electronic Government, Juridical Intelligence and Systems and \\ WBSA Sistemas Inteligentes S.A. \\ hugo.hoeschl@wbsa.com.br \\ ${ }^{4}$ WBSA Sistemas Inteligentes S.A. - irineu.theiss@wbsa.com.br \\ ${ }^{5}$ Institute of Electronic Government, Juridical Intelligence and Systems - \\ tania@ijuris.org
}

\begin{abstract}
The present paper is about applying competence modeling for a knowledge engineer in the case of the company WBSA Sistemas Inteligentes S.A. The process was based on Lucia and Lepsinger model, by which competences are characterized through the identification of situations and behaviors considered relevant to the engineer performance. As one of the different techniques suggested by the model for collecting data, a number of individual interviews were undertaken and at the end it was defined and validated a set of eleven competence regarded as necessary for a satisfactory performance of a knowledge engineer.
\end{abstract}

\section{Introduction}

Knowledge-based systems (KBS) are computer programs that use explicitly represented knowledge to solve problems. Such systems handle knowledge and information by an intelligent manner and are used to solve problems that require a high volume of specialized knowledge [1].

To build a knowledge-based system implies to create a computational model with the objective of developing the capability of solving problems similar to the capability of a domain specialist [2].

In this context, the Knowledge Engineer plays an essential role since he will be the actor responsible for sharing with the specialists his procedures, strategies, and practical rules to solve problems and for building that knowledge into an intelligent system. When this process is correctly performed the result is a system that provides solutions similarly to a human specialist.

Please use the following format when citing this chapter:

Nicolini, A.T., Santos, C.S., Hoeschl, H.C., Theiss, I., Bueno, T.C.D., 2006, in IFIP International Federation for Information Processing, Volume 218, Professional Practice in Artificial Intelligence, eds. J. Debenham, (Boston: Springer), pp. $151-159$ 
The objective of this paper is to present the competence modeling process for the Knowledge Engineer, identifying the set of knowledge, skills, and attitudes required for a high performance of the engineer.

\section{The Concept of Competence}

Due to the diversity of knowledge domains where the concept of competence is applied, it is acceptable that there is no consensus about its definition. That is true even in the context of management.

According to Woodruffe [3], at the center of the debate about management a sensitive field is found where the term competence brings a different meaning when used by different people.

Ruzzarin, Amaral and Simionovisci [4] say that there is no doubt that the concept of competence is at the same time one of the concepts most commonly used and one of the most controversial one in the modern language of management.

Currie and Darby stated that the concept became popular due to Boyatzis, who defined competence as the characteristics of a person that can be observed and can be expressed in terms of motivation, skills, and aspects related to his image or role or the amount of knowledge.

Despite the historical importance of the concept presented by Boyatzis, it is considered too broad and its usage is limited to the field of organizational management. More objective definitions as the one presented by Parry [6] become more commonly used. Parry defines competence as a set of knowledge, skills, and attitudes that mostly affect a work, and keep a relation with the performance; they can be measured through some accepted tools and can be improved by training and development.

As per Cooper [7], the four criteria presented by Parry should be used when defining the profile of competence inherent to a function or a position. Given that any characteristic not included in those criteria should be excluded from the definition of a profile, from the set of factors defining a competence the author eliminates personality traces, capabilities, abilities and attitudes.

Contrary to the approach of Cooper, for Lucia and Lepsinger [8] characteristics as attitudes and capabilities are important for the success in some specific positions, although they having a more subjective character. Another relevant aspect is that even characteristics not so easily quantifiable can be measured and evaluated when translated into behaviors.

The approach based on behaviors was first developed by McClelland and shows wide acceptance by models used nowadays, because "it is only through their behaviors that human beings affect the context where they act" [9].

In line with this perspective, Lucia and Lepsinger suggest that the definition of a competence can be represented in a similar way to a pyramid, the pyramid of competences. As shown by Figure 1, at the top are the behaviors and the base, which provides support to the behaviors, is structured by the skills, knowledge, abilities, and personal characteristics. 


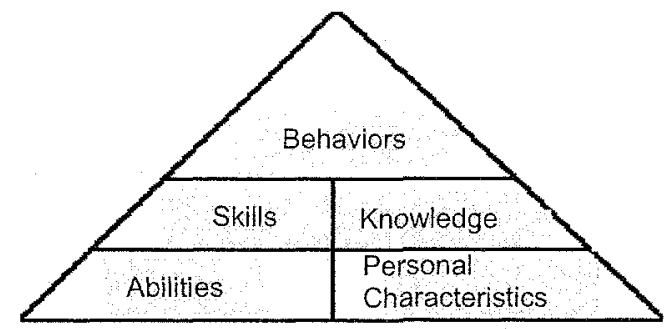

Fig. 1 - Pyramid of competences - Lucia and Lepsinger (1999)

This paper is based on the concept of competence presented by Lucia and Lepsinger. It is considered more adequate because it takes into account attitudes and other subjective, personal characteristics as part of competence.

Furthermore, the chosen model turns possible to measure and evaluate those components of competence due to the fact that it uses the approach based on behaviors to describe competences.

On the other hand, the concept proposed by the above mentioned authors keeps compatibility to the work of Parry and McClelland, which are regarded as important references in the field of management based on competences.

\section{Competence Modeling}

As stated above, the present paper keeps coherence with the concept of competence proposed by Lucia and Lepsinger. Three steps are considered when applying the model: planning, development, and finalizing and validating the model.

\subsection{The case study}

\subsubsection{The Company}

WBSA Sistemas Inteligentes S.A. was created in the context of the knowledge era. It is an Information Technology company in line with the worldwide avantgarde in terms of applying artificial intelligence techniques to information systems.

The origin of the company is strongly linked to university post-graduate programs, still maintaining academic and research partnership with them.

Years of research and development efforts undertaken by WBSA team consolidated the excellence of its intellectual capital, which is recognized worldwide through more than fifty papers already presented and edited by international conferences.

The company developed its expertise in providing solutions based on artificial intelligence techniques for knowledge management systems. In this regard WBSA is recognized by the Brazilian Software Companies Association (ABES) for having well-known specialization.

WBSA stated as its mission "to provide the best intelligence resources applied to the use of information". 


\subsubsection{The Working Process}

With the aim of applying the competence modeling for the company, the first step was to prepare the map of processes undertaken by WBSA. It consists of

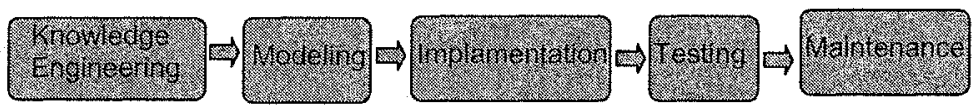

understanding the processes, detailing activities, and collecting information about inputs and outputs [10]. Figure 2 shows the company's workflow.

Fig. 2 - Processes in WBSA

\subsubsection{The Position of Knowledge Engineer}

The term Knowledge Engineering is used to describe the whole development process of knowledge-based systems. It is part of the process a special way of interaction between the system developer, called the knowledge engineer, and one or more specialists on the knowledge domain [11].

In the past, knowledge engineering was the process of transferring knowledge from the specialist into the system knowledge base. That approach normally caused failures because it is not possible for the specialist to translate into words all the knowledge involved in his task [12].

The objective of the knowledge engineering process is to capture the knowledge of a domain specialist, as well as his forecast and control procedures on the subject. This process involves becoming familiar with the domain, to collect information, to do analysis and evaluate the effort required by the project. Furthermore, the knowledge being accumulated has to be codified and tested; the scope of work has to be defined, establishing exactly what the user requires to be efficiently retrieved; the quantity and quality of documents have to be analyzed; and the construction of the vocabulary to support the retrieving process.

\subsection{Applying the model}

\subsubsection{Planning}

The definition of the objectives and scope of the project took as reference the analysis of the critical organizational process with the aim of establishing a competence model for a relevant position in the organization.

Given the importance of the role of the knowledge engineer for the success of the system implementation phase, the knowledge engineering process was elected as a critical process for the Company. And the position of knowledge engineer was chosen to apply the model.

Afterwards the expected result of the project was discussed and the different phases and activities were described. 


\subsubsection{Development}

Data Gathering: was done through individual interviews with the three professionals working as knowledge engineers in the organization, following the questionnaire proposed by Lucia and Lepsinger.

Situations and behaviors observed along the interviews and used as reference for identifying knowledge, attitudes, and skills required for a knowledge engineer are shown on Tables 1,2 and 3.

The three interviewers produced separate tables with their own observations, which were then evaluated to form a consensus about the internal competence model. Each one of the items included in the competence model (knowledge, skills, and attitudes) was clearly defined and the result is shown on the Tables.

\subsubsection{Competence Modeling}

Table 1. Knowledge required for a knowledge engineer

\begin{tabular}{|c|c|c|}
\hline ( & 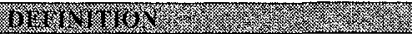 & (I) \\
\hline Business modeling & $\begin{array}{l}\text { To know how to apply techniques for } \\
\text { users interaction with the aim of } \\
\text { understanding the problems of the } \\
\text { organization and identifying potential } \\
\text { improvements as part of the system } \\
\text { requirements. }\end{array}$ & $\begin{array}{l}\text { To define the needs and knowledge } \\
\text { requircd by the client to improve his } \\
\text { tasks }\end{array}$ \\
\hline $\begin{array}{l}\text { Requirements } \\
\text { (system modeling) }\end{array}$ & $\begin{array}{l}\text { To know how to use techniques to } \\
\text { establish the requirements for the } \\
\text { system development }\end{array}$ & $\begin{array}{l}\text { To work in the system development, in } \\
\text { data and user's expectations gathering, } \\
\text { and to pass it on to the development } \\
\text { team. }\end{array}$ \\
\hline $\begin{array}{l}\text { Organizational context } \\
\text { analysis methodology }\end{array}$ & $\begin{array}{l}\text { To know how to use tcchniques and } \\
\text { tools for understanding the } \\
\text { organization context, process, } \\
\text { personnel and technologies mapping }\end{array}$ & $\begin{array}{l}\text { Organization context: mapping of } \\
\text { processes, people, functions, and } \\
\text { existing technologies to identify } \\
\text { opportunities of implementing } \\
\text { technology }\end{array}$ \\
\hline $\begin{array}{l}\text { Knowledge representation } \\
\text { altematives }\end{array}$ & $\begin{array}{l}\text { In the context of Artificial lntelligence, } \\
\text { to represcnt knowledge means to make } \\
\text { it explicit in such a way that a system } \\
\text { can understand and take decisions close } \\
\text { to what a specialist would do }\end{array}$ & $\begin{array}{l}\text { Knowledge organization } / \text { non- } \\
\text { structured documents. To implement } \\
\text { knowledge representation in the form } \\
\text { of ontologies. To organize content in } \\
\text { the form of ontologies }\end{array}$ \\
\hline $\begin{array}{l}\text { The use of ontologics cditor } \\
\text { and Word extractor }\end{array}$ & $\begin{array}{l}\text { The ontologies editor and the extractor } \\
\text { are tools developed to facilate the } \\
\text { process of extracting, organizing, and } \\
\text { representing the knowledge involved in } \\
\text { the process of developing an intelligent } \\
\text { software }\end{array}$ & $\begin{array}{l}\text { The use of tcchrological tools: } \\
\text { extractors and search engines }\end{array}$ \\
\hline $\begin{array}{l}\text { Framework and system } \\
\text { functions }\end{array}$ & $\begin{array}{l}\text { Understanding the product to be } \\
\text { offered to the user is essential in the } \\
\text { process of business prospects. } \\
\text { Communication is facilitated when one } \\
\text { knows the linits of the proposal, the } \\
\text { implementation timeframe and the } \\
\text { complexity of the system features }\end{array}$ & $\begin{array}{l}\text { Understanding technology: not how to } \\
\text { program, but to know how the system } \\
\text { works and what is the role of ontology. } \\
\text { Identifying interfaces that provide } \\
\text { answers to the client needs. To } \\
\text { understand the functions of the tool. }\end{array}$ \\
\hline $\begin{array}{l}\text { Basic informatics } \\
\text { searching tools }\end{array}$ & $\begin{array}{l}\text { Office and searching tools are used to } \\
\text { produce reports, proposals, manuals, } \\
\text { presentations, and research about the } \\
\text { client domain on the Internet }\end{array}$ & $\begin{array}{l}\text { Searching the Internet (Google, clicnts } \\
\text { sites, bibliography, Word, PowerPoint, } \\
\text { Excel, Extractors) }\end{array}$ \\
\hline Project management & $\begin{array}{l}\text { Set of concepts, techniques, and tools } \\
\text { required for project planning and } \\
\text { control }\end{array}$ & $\begin{array}{l}\text { Follows the development work related } \\
\text { to the client expectations fulfillment }\end{array}$ \\
\hline Interpersonal & Set of techniques used to facilitate the & To interact with the client for \\
\hline
\end{tabular}




\begin{tabular}{|c|c|c|}
\hline 1001,2112 & 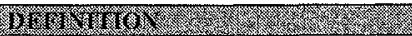 & 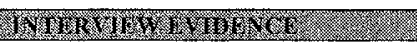 \\
\hline techniques & $\begin{array}{l}\text { contact and communication with other } \\
\text { people or groups }\end{array}$ & $\begin{array}{l}\text { establishing empathy and knowledge } \\
\text { exchange }\end{array}$ \\
\hline Con & $\begin{array}{l}\text { Techniques and methodologies } \\
\text { required for negotiation and mediation }\end{array}$ & $\begin{array}{l}\text { Ontologies delivered did not kecp } \\
\text { coherence with the subject. Absence of } \\
\text { knowledge sharing }\end{array}$ \\
\hline $\begin{array}{l}\text { Interview mo } \\
\text { document ana }\end{array}$ & $\begin{array}{l}\text { To know interview techniques } \\
\text { content extraction techniques }\end{array}$ & $\begin{array}{l}\text { Interview and document analysis. TO } \\
\text { extract the clients reasoning }\end{array}$ \\
\hline
\end{tabular}

Table 2. Skills of a knowledge engineer

\begin{tabular}{|c|c|c|}
\hline 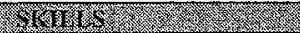 & 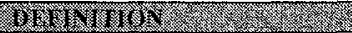 & r \\
\hline Systemic vision & $\begin{array}{l}\text { To see more than just specific } \\
\text { and technical subjects, analyzing } \\
\text { all the aspects involved in the } \\
\text { system development }\end{array}$ & $\begin{array}{l}\text { To interact with all and everything, in line with } \\
\text { the company's strategy. Possibility of systemic } \\
\text { vision }\end{array}$ \\
\hline Facility of synthesis & $\begin{array}{l}\text { Capacity of resuming and } \\
\text { detecting the priorities for }\end{array}$ & $\begin{array}{l}\text { To develop efficient knowledge transfer } \\
\text { mechanisms. To identify tasks of the specialist } \\
\text { that can be done with the tool. Resuming and } \\
\text { defining concepts for the system }\end{array}$ \\
\hline $\begin{array}{l}\text { Facility for systemic } \\
\text { thinking }\end{array}$ & $\begin{array}{l}\text { To classify information and } \\
\text { actions according to its } \\
\text { importance and influence in the } \\
\text { system planning }\end{array}$ & $\begin{array}{l}\text { Support material production (manual, guide } \\
\text { books, ontologies) }\end{array}$ \\
\hline Leadership & $\begin{array}{l}\text { Capacity of leading people or } \\
\text { group of people to accept ideas } \\
\text { and to work for a common } \\
\text { objective }\end{array}$ & $\begin{array}{l}\text { If the client does not understand the importance } \\
\text { of his participation, it can be harm the system } \\
\text { development }\end{array}$ \\
\hline Organization & $\begin{array}{l}\text { Capacity of organizing his own } \\
\text { work, promptly solving } \\
\text { problems or delegating what is } \\
\text { urgent }\end{array}$ & $\begin{array}{l}\text { Absence of process formalization can be the } \\
\text { reason for a bad development process. To } \\
\text { develop efficient mechanisms for knowledge } \\
\text { transfer }\end{array}$ \\
\hline Capacity to take decisions & $\begin{array}{l}\text { To do the best choice of } \\
\text { alternatives, analyzing the } \\
\text { opportunity and viability of the } \\
\text { decision }\end{array}$ & Increase in the perception of defining priotities \\
\hline Team working & $\begin{array}{l}\text { Capacity of interacting with the } \\
\text { group to become influent and } \\
\text { accept influence }\end{array}$ & $\begin{array}{l}\text { To improve processes performed collectively. To } \\
\text { work in synchronicity doing group meetings and } \\
\text { disseminating knowledge }\end{array}$ \\
\hline To work under pressure & $\begin{array}{l}\text { To develop the work under } \\
\text { urgency, maintaining emotional } \\
\text { eguilibrium and behavior }\end{array}$ & $\begin{array}{l}\text { Due to short timing used only two persons to } \\
\text { construct ontologies. Need of negotiating the } \\
\text { term period }\end{array}$ \\
\hline $\begin{array}{l}\text { Capacity of moderation } \\
\text { and negotiation }\end{array}$ & $\begin{array}{l}\text { Capacity of maintaining good } \\
\text { understanding, consensus, and } \\
\text { action to pursue common } \\
\text { objectives }\end{array}$ & $\begin{array}{l}\text { Interface between the client and system } \\
\text { developers. Not enough contact with the client } \\
\text { and lack of scope of work }\end{array}$ \\
\hline Influence & $\begin{array}{l}\text { Capacity of influencing and } \\
\text { leading people to attain a } \\
\text { common objective }\end{array}$ & $\begin{array}{l}\text { If the chicnt does not understand the importance } \\
\text { of his participation, it can be harm the system } \\
\text { development. Contact with the client to obtain his } \\
\text { agreement }\end{array}$ \\
\hline Communication skills & $\begin{array}{l}\text { To present ideas in a clear, } \\
\text { objective and consistent way, } \\
\text { respecting the audience and } \\
\text { making sure the message was } \\
\text { understood }\end{array}$ & $\begin{array}{l}\text { To work in synchronicity doing group neetings } \\
\text { and disseminating knowledge. Communication } \\
\text { ability }\end{array}$ \\
\hline
\end{tabular}

Table 3. Attitudes of a knowledge engineer

\begin{tabular}{|c|c|c|}
\hline (2) 121,1612 & $171 / 211 \% 3$ & 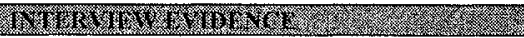 \\
\hline Pati & $\begin{array}{l}\text { Listen, listen, listen... keeping good } \\
\text { humor }\end{array}$ & $\begin{array}{l}\text { capacitation of specialists who will help to define } \\
\text { the system }\end{array}$ \\
\hline Curiosity & Professional growth and development, & To identify clients needs and to define sys \\
\hline
\end{tabular}




\begin{tabular}{|c|c|c|}
\hline WOW & 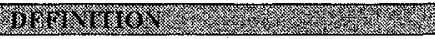 & 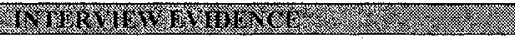 \\
\hline Researcher profile & $\begin{array}{l}\text { with authonomy and secking an adequate } \\
\text { way of improving knowledge }\end{array}$ & functions. To obtain knowledge from the client \\
\hline Proactivivity & $\begin{array}{l}\text { To start working by his own and } \\
\text { influencing the course of action }\end{array}$ & To work intuition/action \\
\hline Soci & $\begin{array}{l}\text { Interact with different groups preserving } \\
\text { its individuality, cooperating and } \\
\text { exchanging cxperiences with the group. }\end{array}$ & Interact with everyt \\
\hline Comt & $\begin{array}{l}\text { Take part actively in meetings, asking, } \\
\text { informing and answering. }\end{array}$ & $\begin{array}{l}\text { Assure a apt team for a continuous ontologies } \\
\text { development work. } \\
\text { Continuous sharing (basic premise) }\end{array}$ \\
\hline Flex & $\begin{array}{l}\text { Experiment, accept and adapt easily to } \\
\text { new situations related to the work. }\end{array}$ & $\begin{array}{l}\text { Interact and solve communication problems. } \\
\text { Necessity of interaction with clients, developers } \\
\text { and commercial department. }\end{array}$ \\
\hline Cre & $\begin{array}{l}\text { Present new patterns, ideas and } \\
\text { innovative solutions in the development } \\
\text { of systems. }\end{array}$ & $\begin{array}{l}\text { Identify specialist's tasks that the tool may } \\
\text { perform. } \\
\text { Constriction of support material (manuals, } \\
\text { reports, ontologies). }\end{array}$ \\
\hline Dipl & $\begin{array}{l}\text { Ability to present him/herself in a } \\
\text { manner in which the relationships are } \\
\text { kept in a higher degree of respect, } \\
\text { pursuing associations and consensus in } \\
\text { diffucult situations. }\end{array}$ & $\begin{array}{l}\text { Interact with the client to establish a empathy } \\
\text { process and knowledge exchange. } \\
\text { Make the developer understand what the client } \\
\text { wishes and make the elient understand the } \\
\text { developer. }\end{array}$ \\
\hline Resp & $\begin{array}{l}\text { Assure that hisher action transmits } \\
\text { confidence to the others, keeping them } \\
\text { tranguil. }\end{array}$ & $\begin{array}{l}\text { New discussions about the process and restarting. } \\
\text { Convince the client is a challenge. }\end{array}$ \\
\hline Determination & $\begin{array}{l}\text { Keep focus to reach the defined goal, } \\
\text { overwhelming cventual difficulties. }\end{array}$ & $\begin{array}{l}\text { Feeling of satisfaction by the client and the } \\
\text { Knowledge Engineer, giving the idea that the } \\
\text { path chosen was the cortect one. }\end{array}$ \\
\hline Compromise & $\begin{array}{l}\text { Show availability, assuring that the } \\
\text { collective results will be reached. }\end{array}$ & $\begin{array}{l}\text { Follow the development of the systems. } \\
\text { The lack of compromising must be avoided. }\end{array}$ \\
\hline
\end{tabular}

\subsection{Finalizing and validating the model}

During this phase, the internal competence model was presented to a group of people working in the same environment, but not in the same position, with the aim of doing an analysis of the general model and identifying those competences regarded as essential for the performance of the knowledge engineer.

Since the knowledge engineer interacts with most of the other people working in the company, it was not difficult to form the focus group to discuss and validate the model.

As presented on Tables 1, 2, and 3 there were identified thirty-three competences, from which eleven is the number of knowledge abilities, eleven are skills, and eleven are attitudes.

With the output of the evaluation phase, a focus group discussion was conducted with the objective of refining the model. The result presented on Table 4 shows a list of competences regarded as being essential for a satisfactory performance of a knowledge engineer in the context of the company WBSA.

Table 4. Essential competences of a knowledge engineer

\begin{tabular}{|l|l|l|l|}
\hline & & & \\
\hline
\end{tabular}


It was verified that, based in the studies about Competences Modelling, the best practice is to identify 5 to 9 competences for each function. That was the goal during this phase, but the conclusion was that, because of the complexity in performing the function, it became crucial to consider the set of competences listed in table 04.

Validate the model and determine the correlation of the competences with the best performances: As this model is being constructed to allow the training and development of the Knowledge Engineers, the application of this phase in the model (a $360^{\circ}$ evaluation) was not necessary. The evaluation made in the precedent phase was enough to identify the competences that assure the good performance of the evaluated function.

Finalizing the model: Considering the complexity of the position being analysed, it is understood that the competences identified by the focal group are actually those that must be worked essentially in all Knowledge Engineers of the company. However, the other competences surveyed in the precedent phase (temporary model).

So, it is considered that the competences identified as essential must be searched for the position of Knowledge Engineering; the other may be worked by the company in its training processes and developments, aiming at the improvement and ideal performance of its collaborators.

\section{Conclusions}

The position of Knowledge Engineer is relatively new, beginning with the emerging of expert systems in the 80 's. With the evolution of the knowledge based systems the position changed its characteristics considerably. So, the establishment of the competences was very interesting as it wasn't a position with consolidated characteristics as opposed to a traditional position.

This research established the competences necessary to the position of Knowledge Engineer in the company WBSA Sistemas Inteligentes SA using Lucia's and Lepsinger's model.

Following the model proposed by the above mentioned authors, the competence modelling may start from a list of competences previously established or from a new one, specifically for the position. In this work, because of the particularities of the position, the second option was adopted.

In the application of the model, some phases were not performed or were adapted, aiming a satisfactory development of the work.

The choice of the position was made taking as reference the mapping of processes and the concept of critical organizational processes.

In this sense, interviews where made with collaborators that occupy this position in the company, and a provisory model of competences was established and lately validated by a broader group. A relevant question diagnosed in the process was the difficulty in differentiate the abilities and attitudes related with the competences identified.

At the end of the process the twelve essential competences to the satisfactory performance by the Knowledge Engineer were established and defined. This list will be initially used in the training and development activities, and may be 
lately expanded for the other activities of the process of human resources management.

Beyond the benefit related with the competences modelling, other positive aspect of the application of the model was the reflection exercise made during the interviews about the role of the Knowledge Engineer in the context of the company. This reflection was useful as the company had already worked in the formalization of its responsibilities.

\section{References}

1 REZENDE, Solange Oliveira. Sistemas Inteligentes: fundamentos e aplicações. Barueri, SP: Manole,2003.

2 STUDER, R. et al., Situation and Perspective of Knowledge Engineering. In: J, Cuena, et al. (eds.), Knowledge Engineering and Agent Technology. IOS Press, Amsterdam, 2000.

3 WOODRUFFE, C. Competent by any other name. Personnel Management, Vol. 23, No, 9, September 1991, pp. 30-33.

4 RUZZARIN, Ricardo. AMARAL, Augusto. SIMIONOVSCHI, Marcelo. Gestão por competências: indo além da teoria. Porto Alegre: Sebrae/RS, 2002.

5 CURRIE, Graeme, DARBY, Roger. Competence-based management development: Rhetoric and reality. Journal of European Industrial Training. Bradford: 1995. Vol.19, Num. 5; pp. 11-19.

6 PARRY, Scott B. Just what is a competency? (And why should you care?). Training. June 1998. Vol.35. Num. 6. pp. 58-61.

7 COOPER, K. C. Efective competency modeling \& reporting. New York: Amacon, 2000.

8 LUCTA, A.D.; LEPSINGER, R. The art and science of competency models. San Francisco: Jossey-Bass, 1999.

9 BECKER, Brian E. HESELID, Mark A. ULRICH, Dave. Gestão estratégica de pessoas com o scorecard: interligando pessoas, estratégia e performance. Rio de Janeiro: Campus, 2001.

10 LGTI - Laboratório de Gestão Tecnologia e Inovação. Universidade Federal de Santa Catarina. Disponivel em: http://www.lgti.ufsc.br/posgraduacao/. Acesso em: 20 de maio de 2005

11 BUENO, Tania. Engenharia das Mentes. Tese (Doutorado em Engenharia de Produção) --Universidade Federal de Santa Catarina, Florianópolis. 2005.

12 SCHREIBER, Guus; et al. Knowledge Engineering and Management: The CommonKADS Methodology. Londres: MIT Press, 2002.

13 SANTOS, Armando C. O uso do método Delphi na criação de um modelo de competências. Revista da Adninistração. Vol. 36, No. 02, pp. 25-32, abril/junho 2001.

14 SHIPPMANN, Jeffery S. ASH, Ronald A. CARR, Linda. HESKETH, Beryl, et al. The pratice of competency modeling. Personnel Psychology. Durham: Autumn 2000. Vol. 53, Num. 3; pp. 703-740. 